Alicja LESKA*

\title{
W KRECGU PROBLEMATYKI STOSUNKÓW KOŚCIOŁA I PAŃSTWA W ŚWIECIE PÓŹNEGO ANTYKU
}

V wiek był epoką najazdów barbarzyńskich i wędrówek ludów, które w szczególny sposób dotknęły zachodnią część cesarstwa rzymskiego, osłabionego kryzysem trwającym już co najmniej od dwu wieków. Podczas tych zawirowań droga obu cesarstw rozchodziła się na zawsze, a zwycięskie chrześcijaństwo zmieniło bezpowrotnie historię Europy Zachodniej. Chrześcijańskie czasy stały się ,działem wodnym” rzymskiej historii ${ }^{1}$.

1. Od religii prześladowanej do religii państwowej. U swego zarania chrześcijaństwo było postrzegane jako religia antypaństwowa, a Kościół jako instytucja aspołeczna ${ }^{2}$, pozostająca w konflikcie z administracją cesarska. Dlatego właśnie aż do początku IV w. chrześcijaństwo było nie tylko prawnie nieuznawane, ale i prześladowane. Z jednej więc strony obserwujemy brak aprobaty dla Kościoła ze strony społeczeństwa i państwa ziemskiego, z drugiej zaś realizowaną przez państwo ideologię, która kwestionuje istnienie Kościoła, a ponadto go prześladuje. Zrównanie chrześcijaństwa z kultami pogańskimi i zaniechanie prześladowań dał Kościołowi tzw. „edykt mediolański” (313) Trudno przy tym definitywnie rozstrzygnać, czy Konstantyn I został sympatykiem chrześcijaństwa bardziej z powodów osobistych, czy politycznych ${ }^{4}$. Nie można bowiem całkowicie wykluczyć, że skłonił się on ku chrześcijaństwu z tej przede wszystkim przyczyny, aby zapewnić przetrwanie Rzymowi

* Dr Alicja Leska - absolwentka filologii klasycznej na Wydziale Polonistyki Uniwersytetu Warszawskiego; wykładowca języka łacińskiego w Wyższej Szkole Inżynierii i Zdrowia w Warszawie; e-mail: alicjaleska@interia.pl.

${ }^{1}$ Por. R.A. Markus, Chrześcijaństwo w świecie rzymskim, tłum. R. Turzyński, Warszawa 1978, 87.

${ }^{2}$ Por. K. Zakrzewski, U schyłku świata antycznego, Warszawa 1964, 5-21; M. Starowieyski, Pisarze pogańscy o chrześcijaństwie, PP 1985, nr 1, 20-21; S. Bralewski, Watki polityczne w oskarżeniach kierowanych przeciwko biskupom w późnym cesarstwie rzymskim, w: Studia z dziejów średniowiecza i czasów nowożytnych, red. S.M. Zajączkowski, Acta Universitatis Lodziensis. Folia Historica 67, Łódź 2000, 7-22.

${ }^{3}$ Por. K. Bihlmeyer - H. Tüchle, Historia Kościoła, t. 1: Starożytność chrześcijańska, tłum. J. Klenowski, Warszawa 1971, 211.

${ }^{4}$ Por. R. Folz, L'idée d'Empire en Occident du $V^{e}$ au XIV siècle, Collection Historique, Paris $1953,259$. 
i tradycyjnej cywilizacji, odziedziczonej po epoce hellenizmu, ocalić je przed wewnętrzną anarchią i atakiem barbarzyńców ${ }^{5}$. Faktem jest, że zmiana nastawienia do tej religii została dokonana w momencie, gdy cesarstwo przechodziło ogromny kryzys gospodarczy ${ }^{6}$. Od tej pory, poza krótką przerwą podczas panowania Juliana Apostaty (361-363), chrześcijaństwo nie doznawało już niepokojów. Jego status religii państwowej ostatecznie ustalił dopiero Teodozjusz Wielki (379-395), który niemal natychmiast po przyjęciu chrztu wydał edykt De fide catholica ${ }^{7}$, wyrażający wolę cesarza, aby wszyscy jego poddani przyjęli wyznanie nicejskie. W ten sposób chrześcijaństwo stało się religią państwową, a Kościół zyskał stanowisko uprzywilejowane ${ }^{8}$. Kapłani i diakoni otrzymali tytuł illustres, a biskupi rzymscy gloriosissimi $i^{9}$ i w konsekwencji stali się poddanymi cesarza, podzielającymi jego negatywny stosunek wobec pogan, heretyków i żydów. W wyniku dalszej ewolucji Kościół jako oficjalna instytucja, wspierana przez cesarzy i urzędników państwowych, mozolnie i nie bez konfliktów wewnętrznych, został osadzony na fundamentach dogmatyczno-prawnych ${ }^{10}$. W taki więc sposób państwo rzymskie pod koniec IV w. stało się państwem chrześcijańskim ${ }^{11}$. Rzym, miasto doczesne Romulusa, przekształcił się w miasto duchowe św. Piotra, ze względu na którego papież otrzymał prymat honorowy ${ }^{12}$.

Katolicki Kościół związany został silnie z ówczesnym państwem, które popierał, zaś władcy cesarstwa rzymskiego stali się protektorami Kościoła ${ }^{13}$. Opieka ta stała się obowiązkiem cesarzy na mocy przyjętej przez nich teologii politycznej ${ }^{14}$. W tej sytuacji, gdy sacrum i profanum zespoliły się, działania

\footnotetext{
${ }^{5}$ Por. H.-I. Marrou, Zmierzch Rzymu czy późna starożytność? III-VI wiek, tłum. M. Węcowski, Warszawa 1997, 23.

${ }^{6}$ Por. Folz, L'idée d'Empire en Occident du Ve au XIV siècle, s. 260.

${ }^{7} \mathrm{~W}$ lutym 380 r. sygnowany formalnie imionami Teodozjusza I, Gracjana i Walentyniana, por. CTh XVI 1, 2; CJ I 1, 1.

${ }^{8} \mathrm{~S}$. Bralewski (Imperatorzy późnego cesarstwa rzymskiego wobec zgromadzeń biskupów, Łódź 1997, 8) uważa, że właściwie już Konstantyn Wielki uczynił z chrześcijaństwa religię uprzywilejowaną. Por. J. Gaudemet, La légalisation religieuse de Constantin, „Revue d'histoire de l'Église de France" 33 (1947) nr 122, 25-61 = J. Gaudemet, Église et Societé en Occident au Moyen Âge, London 1984, 26-48.

${ }^{9}$ Por. M. Banaszak, Historia Kościoła katolickiego, I, Warszawa 1986, 137; P. Brown, Świat późnego antyku, tłum. A. Podzielna, Warszawa 1993, 189.

${ }^{10}$ Por. H.-I. Marrou, L'Église de l'Antiquité tardive 303-604, Paris 1985; Bralewski, Watki polityczne w oskarżeniach kierowanych przeciwko biskupom, s. 8.

${ }^{11}$ Por. F. Lot, La fin du monde antique et les débuts du Moyen Âges, $2^{\mathrm{e}}$ section: L'effondrement de l'Empire et l'affaiblissement de l'idée monarchique, Paris 1938, 28.

${ }^{12}$ Przywilej ten mający początek za papieża Damazego (366-384) wzmocnili prawnie jego następcy. Po Damazym jako 26. był papież Syrycjusz (inne kodeksy błędnie podają, że był to papież Ursyn), który rządził Kościołem przez 15 lat i był autorem pierwszych dekretaliów w tej kwestii, por. Cz. Bartnik, Nadzieje upadajacego Rzymu, Warszawa 1982, 9.

${ }^{13}$ Por. Bralewski, Watki polityczne w oskarżeniach kierowanych przeciwko biskupom, s. 8 .

${ }^{14}$ Por. tamże.
} 
przeciw Kościołowi stały się działaniami przeciw państwu ${ }^{15}$. Niewiele brakowało, by i sam Kościół uznać za nowe imperium rzymskie, czemu sprzeciwiał się św. Augustyn w De civitate Dei, przy czym nie potępiał on cesarstwa ziemskiego, ale uważał, że jako ludzkie i świeckie nie jest wieczne.

2. Zanikanie kultu cesarskiego. Do końca epoki rzymskiej historycy Kościoła zajmujący się ideologią i dogmatyką nie załatwili sprawy kultu cesarskiego ${ }^{16}$. W rezultacie cesarz jako zbawca imperium stawiany był niemal na równi ze Zbawcą świata. Poeta Klaudian wyrażał radość ${ }^{17}$, że cesarz chrześcijański upodabniał się do bóstw pogańskich, a Jowisz zaakceptował nowego boga cesarza Teodozjusza I. Jasno widać, że brak obrzędowości chrześcijańskiej pozwalał, pomimo upadku pogaństwa i laicyzacji pewnych funkcji miejskich, ciągle trwać pozostałościom oficjalnego kapłaństwa pogańskiego. Najwyraźniej chrześcijańscy władcy, już to ze względu na tradycję, już to z przyczyn społeczno-politycznych, tolerowali istnienie kultu cesarskiego. Być może również dlatego zachowano pozbawione dawnej treści stanowiska flaminów miejskich oraz kapłanów prowincjonalnych. Flamines perpetui modlili się nadal za cesarza, ale nie musiał to być ryt oficjalny, którego celem było wyrażenie lojalności wobec rządzącej dynastii i troska o zachowanie jedności cesarstwa, a nie adoracja religijna cesarza. Sakralny charakter jego osoby, zarówno dla chrześcijan, jak i dla pogan, stanowił o przepaści między nim a poddanymi ${ }^{18}$. Dla tych pierwszych jednak największym i jedynie absolutnym cesarzem był Bóg, a cesarz był wybrańcem z woli Boga, który przekazał mu rządy nad wszelkim ziemskim stworzeniem. Cesarze byli ,panami całej ziemi pod słońcem” ${ }^{19}$ oraz ,,panami wszystkich spraw ludzkich”"20. Świadomość misji pozaziemskiej miała jednakże wpływ na charakter władzy cesarskiej. Cesarz miał odtąd ponosić odpowiedzialność przed Chrystusem za dusze swych poddanych. $Z$ powodu tej idei na Zachodzie słabi władcy stawali się jeszcze bardziej ustępliwi wobec żądań duchowieństwa ${ }^{21}$. Biskupi jako władcy kościelni: Ambroży w Mediolanie, Bazyli w Cezarei, Jan Chryzostom w Antiochii i w Konstantynopolu oraz Augustyn w Hipponie, będący pod silnym wpływem ruchu ascetycznego, wierzyli głęboko, że odpowiedzą przed Bogiem za grzechy ludności, żądali zatem pomocy od cesarzy w rządzeniu

${ }^{15} \mathrm{~Np}$. donatyści, którzy od końca IV w. wielokrotnie wzniecali niepokoje w cesarstwie, będące wyrazem zaciekłego oporu wobec władzy cesarskiej. Por. Bralewski, Watki polityczne w oskarżeniach kierowanych przeciwko biskupom, s. 9.

16 J. Śrutwa (Praca w starożytnym chrześcijaństwie afrykańskim, Lublin 1983, 149) mówi o Kościele afrykańskim, ale z pewnością dotyczy to całego Kościoła.

${ }^{17}$ Por. W. Dziewulski, Zwycięstwo chrześcijaństwa w świecie starożytnym, Wrocław 1969, 99.

${ }^{18}$ Por. J. Strzelczyk, Wandalowie i ich afrykańskie państwo, Warszawa 1992, 217.

${ }_{19}$ Por. G. Alföldy, Historia społeczna starożytnego Rzymu, thum. A. Gierlińska, Warszawa 1991, 245.

${ }^{20}$ Por. tamże, s. 245.

${ }^{21}$ Por. Brown, Świat późnego antyku, s. 127. 
powierzoną im owczarnią2 . Osobistości te w sprawach Kościoła miały wprost władzę absolutną, której nawet władca, jako chrześcijanin bywał podległy. Kiedy więc w 384 r. prefekt Rzymu Kwintus Aureliusz Symmach chciał przywrócić w senacie posag bogini Zwycięstwa, Ambroży przeciwstawił się temu zagroziwszy trzynastoletniemu cesarzowi ekskomunikąa23. Wpłynął też na niedopuszczenie do odprawienia nabożeństwa ariańskiego, mimo życzenia matki Walentyniana II, Justyny ${ }^{24}$. Po zniszczeniu zaś domu sekty chrześcijańskiej i synagogi, dokonanego przez wspólnotę chrześcijan z Callinicum wraz z ich biskupem oraz z mnichami, gdy cesarz kazał im odbudować je na ich koszt, Ambroży zażądał cofnięcia rozkazu, zagroziwszy przerwaniem mszy odprawianej w obecności władcy ${ }^{25}$ i nakazał mu publicznie upokorzyć się za rzeź Tessaloniczan ${ }^{26}$. Uznając swoją władzę za najwyższą w sprawach kościelnych oraz dotyczących moralności chrześcijańskiej, której cesarz musiał się podporządkować ${ }^{27}$, wyraził on swój alternatywny pogląd na stosunki Kościół - państwo $^{28}$. Co prawda w sprawach publicznych i świeckich papież podlegał cesarzowi ${ }^{29}$, ale z punktu widzenia religii władza jego była nadrzędna, gdyż obowiązkiem papieża było zdać relację przed Bogiem z postępowania władców ${ }^{30}$. I z tym trzeba było się liczyć. Istniała przy tym pewna sprzeczność pomiędzy władzą cesarską a papieską, gdyż Kościelna civitas, stanowiąca autonomiczną całość nie była ani substytutem, ani wytworem cesarstwa ${ }^{31}$.

3. Organizacja kościelna a państwowa. Chociaż sobory ekumeniczne zwoływane były przez cesarza, który zatwierdzał decyzje dogmatyczne i dyscyplinarne, to jednak Kościół na Zachodzie był bardziej niezależny od cesarza, niż na Wschodzie ${ }^{32}$. Władza cesarska starała się mieć wpływ na wybór biskupów, ale brak było ku temu podstaw prawnych ${ }^{33}$. Papież Innocenty I w 415 r. orzekł, że zmiany w organizacji państwowej nie zmuszały do zmian w strukturze kościelnej, jednak stopniowo diecezjalne struktury kościelne stały się prawie identyczne $\mathrm{z}$ administracyjnym podziałem cesarstwa ${ }^{34}$. Sobór

\footnotetext{
${ }^{22}$ Por. tamże, s. 136.

${ }^{23}$ Por. Symmachus, Relatio 3, ed. R.H. Barrow: Prefect and Emperor: the „Relationes” of Symmachus a.d. 384, Oxford 1973, 32-47.

${ }^{24}$ Por. Dziewulski, Zwycięstwo chrześcijaństwa w świecie starożytnym, s. 108; R. Collins, Europa wczesnośredniowieczna 300-1000, thum. T. Szafrański, Warszawa 1996, 72.

${ }^{25}$ Por. J. Vogt, Upadek Rzymu, thum. A. Łukaszewicz, Warszawa 1993, 220.

${ }^{26}$ Por. Collins, Europa wczesnośredniowieczna 300-1000, s. 79.

${ }^{27}$ Por. Vogt, Upadek Rzymu, s. 81.

${ }^{28}$ Por. Collins, Europa wczesnośredniowieczna 300-1000, s. 109.

${ }^{29}$ Por. tamże, s. 321.

${ }^{30}$ Por. tamże, s. 259.

${ }^{31}$ Por. M. Banniard, Geneza kultury europejskiej V-VIII w., thum. A. Kuryś, Warszawa 1995, 71.

${ }^{32}$ Por. F. Lot, La fin du monde antique et les débuts du Moyen Âges, Paris 1927, 31.

${ }^{33}$ Por. Banaszak, Historia Kościoła katolickiego, I, s. 137; Brown, Świat późnego antyku, s. 191.

${ }^{34}$ Por. Markus, Chrześcijaństwo w świecie rzymskim, s. 100; Lot, La fin du monde antique, s. 30.
} 
Chalcedoński (451) polecił organizacji kościelnej dostosować się do podziału administracyjnego państwa, zaś biskupom zakazał ubiegać się u władz państwowych o zmiany ich przynależności metropolitalnej. Podobnie, wydająca liczne pisma, kancelaria papieska przyjęła z czasem normy kancelarii cesarskiej ${ }^{35}$.

4. Zmaganie dwóch światów: pogaństwa i chrześcijaństwa na płaszczyźnie społecznej. W sytuacji, gdy stosunki między państwem i Kościołem ustawione zostały na płaszczyźnie większego realizmu ustąpiły teoretyczne przeszkody dla pełnego udziału chrześcijan w funkcjonowaniu aparatu państwowego i społecznego. Chrystianizacja administracji i wojska była uwieńczeniem pozyskiwania dla Chrystusa ważniejszych dziedzin życia zawodowego i społecznego. Sytuacja na tych dwóch płaszczyznach miała istotne znaczenie dla losów politycznych całego cesarstwa. Zmiany dokonały się, mimo, że kadra kierownicza niemal do końca wytrwała przy pogaństwie lub też składała się $\mathrm{z}$ chwiejnych chrześcijan ${ }^{36}$. Mające udział w rządach rodziny arystokratyczne o silnych tradycjach pogańskich, uważając się za strażników rzymskiej konstytucji, czyli za prawnych sędziów rzymskiej religii ${ }^{37}$, prowadziły zdecydowaną walkę z Kościołem, który był według nich zagrożeniem dla mos maiorum $^{38}$. Konflikt między poganami a chrześcijanami dotyczył religijnych podwalin państwa rzymskiego, u podłoża którego leżały faktycznie polityczne i kulturalne ideały klasy senatorskiej ${ }^{39}$.

Cesarz Honoriusz upominał urzędników za popieranie kultu pogańskiego $^{40}$, jednak nadal sympatyzowało $\mathrm{z}$ nim wielu wpływowych ludzi, piastujących nawet najwyższe urzędy, członkowie lokalnych władz ${ }^{41}$, jak np. pretor Messala (399-400), czy prefekt Rzymu Florencjusz (395-397). Rzymski nacjonalizm popierał również zabiegający o poparcie arystokracji patrycjusz rzymski i magister militum Flawiusz Stylichon.

Z możliwością pełnienia służb publicznych na zawsze pogodziła chrześcijaństwo opinia Augustyna, że chrześcijanin nie oddziela szczęścia osobistego od pomyślności ziemskiej ojczyzny. Polecał on szczerze pracować na rzecz państwa ziemskiego, gdyż jedynie solidne wykonywanie obowiązków prowadziło do pokoju w niebie. Praca dla dobra innych ludzi prowadzić miała do Boga, a życie w społeczności ziemskiej przygotowywać miało do życia w społeczności niebiańskiej. Ponadto uzasadniając ideę i zadania chrześcijańskiej

\footnotetext{
${ }^{35}$ Por. Vogt, Upadek Rzymu, s. 214.

${ }^{36}$ Por. Śrutwa, Praca w starożytnym chrześcijaństwie afrykańskim, s. 148.

${ }^{37}$ Por. Markus, Chrześcijaństwo w świecie rzymskim, s. 100; Lot, La fin du monde antique, s. 89.

${ }^{38}$ Por. Alföldy, Historia społeczna starożytnego Rzymu, s. 256.

${ }^{39}$ Por. Markus, Chrześcijaństwo w świecie rzymskim, s. 84-88.

${ }^{40}$ Por. Banaszak, Historia Kościoła katolickiego, I, s. 137; Brown, Świat późnego antyku, s. 143.

${ }^{41}$ Por. Alföldy, Historia społeczna starożytnego Rzymu, s. 253.
} 
cywilizacji oraz państwowej społeczności głosi1 ${ }^{42}$, że moralne jest prowadzenie handlu i posiadanie bogactw.

5. Bogactwo i przywileje Kościoła. Do Kościoła, dla odpuszczenia grzechów, wpłynęła rzeka pieniędzy w postaci dotacji cesarskich, zapisów testamentowych oraz darowizn ${ }^{43}$. Na próżno też asceci atakowali przepych kościołów cesarstwa oraz bazylik Ziemi Świętej ${ }^{44}$. Kościół otrzymał prawo posiadania dóbr ziemskich, a jego duchowni zostali zwolnieni od podatków państwowych i komunalnych. Ze względu na krytyczną sytuację cesarstwa w $441 \mathrm{r}$. Walentynian III uchylił ten przywilej. Sam Kościół popierał zresztą takie decyzje, ponieważ stwierdzono niedociągnięcia duchownych zajmujących się handlem ${ }^{45}$, a zwolnionych od świadczeń, które spełniali kupcy co pięć lat. Zresztą państwo chciało mieć ubogie kadry duchowne, aby nie obciążać zbytnio skarbu państwa, nie opierając tej motywacji na ewangelii, lecz na kalkulacji czysto finansowej ${ }^{46}$. W interesie dworu cesarskiego i jego administracji było widzieć w duchownych jedynie sumiennych i potulnych urzędników, pełniących rolę służebną wobec państwa: zapewnienie mu błogosławieństwa niebios ${ }^{47}$.

6. Bellum iustum i iniustum. Według historyków orientacji protestanckiej, Kościół zawarł z cesarstwem rodzaj nieformalnej umowy. Faktem jest, że uzyskał on w ten sposób gwarancje wpływów i przywilejów za cenę ustępstw dotyczących zasad wiary, a przede wszystkim w sprawie religijnego zakazu zabijania. Trzeba wszakże zwrócić uwagę na konieczność zmiany z jego strony dotychczasowej postawy wobec nasilającego się wciąż niebezpieczeństwa płynącego z najazdów ${ }^{48}$. Konieczność obrony ojczyzny i bliźnich stworzyła pojęcia bellum iustum i bellum iniustum ${ }^{49}$. Nawet Tertulianowi bliskie mogłyby być rozterki, jakie stały się udziałem Bonifacjusza, który rozpatrywał, czy zgodne z miłością chrześcijańską byłoby skazywanie Afryki na chaos i najazdy barbarzyńców ${ }^{50}$.

${ }^{42}$ Por. Bihlmeyer - Tüchle, Historia Kościoła, t. 1, s. 777.

${ }^{43}$ Por. Śrutwa, Praca w starożytnym chrześcijaństwie afrykańskim, s. 44.

${ }^{44}$ Por. J. Jundziłł, Rozdawnictwa pieniędzy w późnym cesarstwie rzymskim, VoxP 16 (1996) t. 30-31, 55; Brown, Świat późnego antyku, s. 136-138.

${ }^{45}$ Cesarz Walentynian III zabronił duchownym zajmować się handlem z powodu tych nadużyć. Por. Bihlmeyer - Tüchle, Historia Kościoła, t. 1, s. 306.

${ }^{46}$ Por. A.H.M. Johnes, The Later Roman Empire, II, Oxford 1964, 442; Śrutwa, Praca w starożytnym chrześcijaństwie afrykańskim, s. 236.

${ }^{47}$ Por. Śrutwa, Praca w starożytnym chrześcijaństwie afrykańskim, s. 236.

${ }^{48}$ Por. tamże, s. 124.

${ }^{49}$ L. Winowski (Stosunek chrześcijaństwa pierwszych wieków do wojny, Lublin 1947, 53-56) pisze o tym, jak można było zostać żołnierzem i służyć państwu w ówczesnej, nowej rzeczywistości. Por. A.G. Hamman, Życie codzienne w Afryce Pólnocnej w czasach św. Augustyna, tłum. M. StafiejWróblewska - E. Sieradzińska, Warszawa 1989, 396-399.

${ }^{50}$ Por. A. Wypustek-Krzyszowski, Chrześcijanie a armia rzymska - „De corona militis” Tertuliana, w: Pod znakami Aresa i Marsa. Materiaty z konferencji naukowej „,Wojna i wojskowość 
Doktrynę wojny sprawiedliwej stworzył Augustyn, argumentując, że można dla dobra Christianitas odejść od przykazania: „miłujcie waszych nieprzyjaciół" 51 . Dla niego żołnierz zabijający na wojnie nie tylko nie popełniał występku, ale nawet w wypadku odmowy wykonania swego rzemiosła, winien byłby zbrodni nieposłuszeństwa i zlekceważenia autorytetu władzy prawowitej $^{52}$. Uważał on ponadto, że nawet w walce można czynić pokój bellando pacificus ${ }^{53}$ i że istnieje różnica między zwykłym morderstwem, a zabijaniem na rozkaz w czasie wojny. Augustyn rozumiał, że zastąpienie służby w wojsku przez wyłączną służbę, ,pod sztandarami Chrystusa” było nierealne ${ }^{54}$. I choć „początek władzy chrześcijańskich cesarzy zdawał się być zapoczątkowaniem ery mesjańskiego pokoju, jednak chrześcijanie w V w. po Chrystusie opiewali, zupełnie jak ich pogańscy poprzednicy, moc Boga przejawiającą się w zwycięskiej przemocy" ${ }^{55}$.

7. Kościół na straży bezpieczeństwa państwa i cywilizacji. Papiestwo zatem stało się sprzymierzeńcem państwa w walce z barbarzyńcami ${ }^{56}$. Dzięki swej jedności i moralnej mocy Kościół położył wielkie zasługi w utrzymaniu porządku i ratowaniu cywilizacji w czasie wędrówki ludów. Wstrząśnięty w sposób podobny jak inne instytucje dawnego porządku, lecz budzący zaufanie, przejął funkcje obrońców podczas inwazji barbarzyńskich w Galii, Italii i Afryce Północnej ${ }^{57}$.

W czasach chaosu biskupi przejmując inicjatywę w sprawach wojskowych organizowali lokalną obronę, naprawiali mury obronne oraz opłacali wojska ${ }^{58}$. Czynili tak m.in. św. Augustyn w Hipponie, św. Anian w Orleanie, św. Paulin w Noli, św. Eucheriusz w Lyonie, Maksym w Turynie, Lupus w Troyes i Synezjusz w Cyrenie ${ }^{59}$. Św. Genowefa znalazła sposób, by statki ze zbożem dotarły do oblężonej Lutecji ${ }^{60}$.

w starożytności”, Kraków, 24-26 września 1993, red. E. Dąbrowa, Zeszyty Naukowe Uniwersytetu Jagiellońskiego 1166, Prace Historyczne, z. 117, Kraków 1995, 138.

${ }^{51}$ Por. W. Pałubicki - J. Iluk, Małżeństwo i rodzina w dawnym judaizmie i starożytnym chrześcijaństwie, Gdańsk 1995, 230.

${ }^{52}$ Synod w Arles (314) w kanonie 3. postanowił o ekskomunikowaniu ludzi uchylających się od służby wojskowej, por. Winowski, Stosunek chrześcijaństwa pierwszych wieków do wojny, s.76.

${ }^{53}$ Por. Wypustek-Krzyszowski, Chrześcijanie a armia rzymska, s. 138.

${ }^{54}$ Por. Śrutwa, Praca w starożytnym chrześcijaństwie afrykańskim, s. 132.

${ }^{55}$ Por. Wypustek- Krzyszowski, Chrześcijanie a armia rzymska, s. 137.

${ }^{56}$ Por. Winowski, Stosunek chrześcijaństwa pierwszych wieków do wojny, s. 136.

${ }^{57}$ Por. Markus, Chrześcijaństwo w świecie rzymskim, s. 97.

${ }^{58}$ Por. Paulus Orosius, Historiarum adversum paganos lib. VII 39, 2, ed. C. Zangemeister, CSEL 5, Vindobonae 1882, 545. Zob. Markus, Chrześcijaństwo w świecie rzymskim, s.100; Vogt, Upadek Rzymu, s. 191-245.

${ }^{59}$ Por. P. Verbraken, Narodziny i wzrost Kościoła od czasów apostolskich do VIII w., thum. K. Dembińska, Katowice 1988, 139; E. Gibbon, Upadek cesarstwa rzymskiego na Zachodzie, thum. I. Szymańska, Warszawa 2000, 38.

${ }^{60}$ Por. Gibbon, Upadek cesarstwa rzymskiego na Zachodzie, s. 277. 
$\mathrm{Na}$ porządku dziennym była praktyka prowadzenia mediacji z wrogiem przez biskupów. Wiele zdziałał w 410 r. dla utrzymania przymierza Honoriusza z Alarykiem biskup Rzymu w latach 402-417 św. Innocenty I ${ }^{61}$. W 449 r. biskup Rzymu Leon I odmówił opuszczenia Rzymu obleganego przez wroga, mimo zaproszenia go na synod w Efezie. W 452 r. pod Mantuą z kolei skłonił Attylę do odwrotu i odejścia za Dunaj. Senat przerażony doniesieniami o spustoszeniach w prowincjach, nie widząc innego wyjścia, przekonał cesarza, by prosić o pokój strasznego barbarzyńcę ${ }^{62}$. Poselstwo, w którym oprócz Leona I uczestniczył także konsul Awien i prefekt Trygecjusz zostało szczególnie godnie przyjęte przez Attylę właśnie ze względu na obecność najwyższego kapłana $^{63}$. Leon I zachował się podobnie w 455 r., gdy Rzym był pozbawiony wszelkiej obrony. Wyszedł naprzeciw Gejzerykowi do bram miasta a jego błagania sprawiły, że barbarzyńca powstrzymał się od ognia, rzezi i tortur w wydanym sobie mieście ${ }^{64}$. Ponadto oddał on swoje dobra dla głodujących Rzymian ${ }^{65}$, a w momencie, gdy pozbawiono władzy Ksystusa i Rzym więcej niż czterdzieści dni był pozbawiony zwierzchnika duchowego okazał też wielką skromność zwlekając z przyjęciem funkcji papieża ze względu na misję państwową w sprawie pojednania między Aecjuszem i Albinem, dla realizacji której przebywał w Galii ${ }^{66}$.

Biskupi prowadzili również pertraktacje dotyczące wykupu jeńców i zdarzało się, że w tym celu sprzedawali naczynia liturgiczne ${ }^{67}$. Cezary, biskup Arles, płacił za wolność nie tylko swych ludzi, ale również Franków i Burgundów. W tym celu kazał przetapiać srebrne sprzęty kościelne ${ }^{68}$.

W sytuacji, gdy w cesarstwie zachodnim władza państwowa załamała się, biskupi będąc równocześnie urzędnikami i rozdawcami dóbr dla członków wspólnoty, angażowali się w utrzymanie normalnego trybu życia ${ }^{69}$. Byli ostoją społeczności miejskiej, gdy władza centralna nie miała już możliwości jej

${ }^{61}$ Por. Paulus Orosius, Historiarum adversum paganos lib. VII 39, 2, CSEL 5, 545. Interwencje w politykę świecką: É. Demougeot, A propos des interventions du pape Innocent I Ir dans la politique séculière, RevH 78 (1954) t. 212, 23-38; Altaner, s. 475.

${ }^{62} \mathrm{R}$. Folz (L'idée d'Empire en Occident du Vé au XIVe siècle, s. 240-241) pisze, że inwazja Attyli na Galię nie była tak straszna, jak na Italię, którą oddalenie jej kosztowało wiele srebra.

${ }^{63}$ Por. Gibbon, Upadek cesarstwa rzymskiego na Zachodzie, s. 285; Vogt, Upadek Rzymu, s. 212 i 255.

${ }^{64}$ Por. Bihlmeyer - Tüchle, Historia Kościoła, t. 1, s. 320; Strzelczyk, Wandalowie i ich afrykańskie państwo, s. 140; P. Pierrard, Historia Kościoła katolickiego, tłum. T. Szafrański, Warszawa 1984, 57; Vogt, Upadek Rzymu, s. 258.

${ }^{65}$ Por. Pierrard, Historia Kościoła katolickiego, s. 58.

${ }^{66}$ Por. tamże, s. 744 i 748.

${ }^{67}$ Por. tamże, s. 57.

${ }^{68}$ Por. M. Mączyńska, Wędrówki ludów. Historia niespokojnej epoki IVi Vw., Warszawa 1996, 38.

${ }^{69}$ Biskupi upoważnieni byli do kontrolowania funkcjonowania lokalnych władz świeckich, co świadczy o braku do nich zaufania ze strony władz centralnych. Por. Dziewulski, Zwycięstwo chrześcijaństwa w świecie starożytnym, s. 108; Collins, Europa wczesnośredniowieczna 300-1000, s. 103; Markus, Chrześcijaństwo w świecie rzymskim, s. 97. 
obrony. Członkostwo we wspólnocie chrześcijańskiej dawało pomoc o wiele bardziej wartościową, niż świeckie obywatelstwo ze swym brzemieniem służby wojskowej i przygniatającym ciężarem finansowej odpowiedzialności. Przyzwyczajeni do cywilnej odpowiedzialności biskupi edukowali i wypełniali puste miejsce po administracji rzymskiej. Pomimo, że często ze względu na swe dyplomatyczne misje narażali się na podejrzenia o konspirację z wrogiem, prosząc o pomoc za granicą przeciw heretykom i barbarzyńcom, to $\mathrm{w}$ istocie okazali większy patriotyzm niż arystokracja pogańska ${ }^{70}$.

\section{Wzrost potęgi Kościoła a upadek cesarstwa zachodniorzymskiego.} Kiedy cesarstwo zachodnie po raz ostatni jako mocarstwo zmagało się z Hunami, dla papiestwa nastąpił czas światowego znaczenia ${ }^{71}$. Podczas, gdy instytucje państwowe traciły siły popadając $\mathrm{w}$ chaos, hierarchia kościelna utrwalała się, co powodowało szybszy jeszcze wzrost potęgi Kościoła i kleru w całej Europie. Z tego względu tradycjonaliści upatrują przyczyn zwycięstwa chrześcijaństwa w upadku Imperium Romanum ${ }^{72}$. Skrajna wydaje się jednak opinia Petera Browna ${ }^{73}$, który uważał, iż upadek cesarstwa zachodniego był ceną, jaką przyszło zapłacić za przetrwanie senatu i Kościoła katolickiego. Fałszem też byłoby utrzymywać, iż osiągnięcie wolności religii na Zachodzie stało się możliwe tylko na gruzach władzy politycznej cesarstwa zachodniego, choć to niewątpliwie otworzyło Kościołowi drogę ${ }^{74}$. Silne organizacje kościelne przejmując funkcje polityczne i wojskowe państwa nie zniszczyły jego struktur. W rzeczywistości Kościół był jedynym organizmem zdolnym zapanować nad dramatem Zachodu i nadać mu sens. To splot okoliczności spowodował, że Kościół przejął rolę cesarstwa ${ }^{75}$.

Tradycjonaliści zapatrzeni w fundamentalne dzieło Edwarda Gibbona ${ }^{76}$ upatrują przyczyny upadku cesarstwa i końca świata antycznego w zwycięstwie chrześcijaństwa. Co prawda nie można zaprzeczyć słuszności jednego z jego argumentów, że za przyjęciem chrześcijaństwa szła akceptacja innych wartości. Chrześcijaństwo niosąc za sobą ideologię pacyfistyczną spowodowało poważne przetasowania w rzymskim systemie wartości ${ }^{77}$. Henry Bergasse jest przy tym zdania ${ }^{78}$, że chrześcijaństwo miało charakter nie tyle pacyfistyczny, co zdecydowanie cywilny. Nie wnikając w subtelności tego rozróżnienia, niewątpliwie zostały wtedy zachwiane dotychczasowe pojęcia męstwa, patriotyzmu

\footnotetext{
${ }^{70}$ Por. Vogt, Upadek Rzymu, s. 235; Alföldy, Historia społeczna starożytnego Rzymu, s. 382.

${ }^{71}$ Por. tamże, s. 256.

${ }^{72}$ Por. M. Mazzarino, The end of the ancient world, London 1966, 61.

${ }^{73}$ Por. Brown, Świat późnego antyku, s. 151.

${ }^{74}$ Por. H. Rahner, Kościół i państwo we wczesnym chrześcijaństwie, tłum. M. Radożycka, Warszawa 1986, 131.

${ }^{75}$ Por. Pierrard, Historia Kościoła katolickiego, s. 55-56.

76 The History of the Decline and Fall of the Roman Empire, vol. 1-12, London 1791-1792.

${ }^{77}$ Por. Vogt, Upadek Rzymu, s. 156.

${ }^{78}$ Por. H. Bergasse, Podzwonne dla Rzymu, tłum. E. Krasnowolska, Warszawa 1981, 152.
} 
i lojalności. Słusznie jednak Roger Collins podważa ${ }^{79}$ argumenty Gibbona, przypominając o dalszym istnieniu chrześcijańskiego cesarstwa wschodniego.

Pozostawiając otwartą kwestię, czy i w jakiej mierze chrześcijaństwo przyczyniło się do upadku Rzymu, bezsprzecznym wydaje się fakt, iż religia ta odmieniła całkowicie i bezpowrotnie stosunki społeczne, polityczne i kulturalne dotąd w nim istniejące. Te trzy aspekty życia natomiast należy badać razem.

\section{ON THE RANGE OF PROBLEMS CONCERNING THE RELATIONSHIP BETWEEN THE CHURCH AND THE STATE IN THE LATE ANTIQUITY}

\section{(Summary)}

Alicja Leska in her article entitled On the range of problems concerning the relationship between the Church and the state in the late Antiquity outlines the way Christianity went from a persecuted religion to a state religion and demonstrates how Christianity changed the political and social relations in the Roman Empire completely and irretrievably. The Author indicates struggle and permeation of two worlds, pagan and Christian, during the economic crisis which started already in the $3^{\text {rd }}$ century $\mathrm{AD}$, barbarian invasions and migration of nations which intensified in the 5th century as well as the division of the Roman Empire. She presents arguments refuting the accusations of those historians who see the cause of Christianity's victory in the ruin of the Roman Empire. Leska emphasizes it was a coincidence that the Church gained world importance at the time of the empire's decline and fall into disorder. The Author points out that the Church, taking over the functions of the empire, was the only body able to manage the crisis of the West and assign meaning toit. Due to the unity and moral power and despite being shaken the same way like other institutions, the Church brought credit maintaining order and saving civilization.

Key words: late Roman Empire, Church, political and social relations.

Słowa kluczowe: późne cesarstwo rzymskie, Kościół, stosunki politycznospołeczne.

\section{BIBLIOGRAFIA}

\section{Źródła}

Paulus Orosius, Historiarum adversum paganos lib., ed. C. Zangemeister, CSEL 5, Vindobonae 1882, 1-564.

Symmachus, Relationes, ed. R.H. Barrow, Prefect and Emperor: the „Relationes” of Symmachus a.d. 384, Oxford 1973.

\footnotetext{
${ }^{79}$ Por. Collins, Europa wczesnośredniowieczna 300-1000, s. 109.
} 


\section{Opracowania}

AlföLdy G., Historia społeczna starożytnego Rzymu, tłum. A. Gierlińska, Warszawa 1991.

Altaner B. - Stuiber A., Patrologia, tłum. P. Pachciarek, Warszawa 1990.

BanaszaK M., Historia Kościoła Katolickiego, I, Warszawa 1986.

BanNiard M., Geneza kultury europejskiej V-VIII w., tłum. A. Kuryś, Warszawa 1995.

Bartnik Cz., Nadzieje upadajacego Rzymu, Warszawa 1982.

Bergasse H., Podzwonne dla Rzymu, thum. E. Krasnowolska, Warszawa 1981.

Bihlmeyer K. - Tüchle H., Historia Kościoła, t. 1: Starożytność chrześcijańska, tłum. J. Klenowski, Warszawa 1971.

BRALEWSKI S., Imperatorzy późnego cesarstwa rzymskiego wobec zgromadzeń biskupów, Łódź 1997.

BRALEWSKI S., Watki polityczne w oskarżeniach kierowanych przeciwko biskupom w późnym cesarstwie rzymskim, w: Studia z dziejów średniowiecza i czasów nowożytnych, red. S.M. Zajączkowski, Acta Universitatis Lodziensis. Folia Historica 67, Łódź 2000, 7-22.

Brown P., Świat późnego antyku, tłum. A. Podzielna, Warszawa 1993.

Collins R., Europa wczesnośredniowieczna 300-1000, thum. T. Szafrański, Warszawa 1996.

Demougeot É., A propos des interventions du pape Innocent $I^{\text {er }}$ dans la politique séculière, RevH 78 (1954) t. 212, 23-38.

DzIEWULSKi W., Zwycięstwo chrześcijaństwa w świecie starożytnym, Wrocław 1969.

Folz R., L'idée d'Empire en Occident $d u V^{e}$ au XIV siècle, Collection Historique, Paris 1953.

Gaudemet J., La légalisation religieuse de Constantin, „Revue d'histoire de l'Église de France" 33 (1947) nr 122, 25-61 = J. Gaudemet, Église et Societé en Occident au Moyen Âge, London 1984, 26-48.

GibBon E., The History of the Decline and Fall of the Roman Empire, vol. 1-12, London 1791-1792.

GibBon E., Upadek cesarstwa rzymskiego na Zachodzie, tłum. I. Szymańska, Warszawa 2000.

Hamman A.G., Życie codzienne $w$ Afryce Pólnocnej $w$ czasach św. Augustyna, tłum. M. Stafiej-Wróblewska - E. Sieradzińska, Warszawa 1989.

Johnes A.H.M., The Later Roman Empire, II, Oxford 1964.

JundzıŁ J., Rozdawnictwa pieniędzy w późnym cesarstwie rzymskim, VoxP 16 (1996) t. 30-31, 49-56.

Lot F., La fin du monde antique et les débuts du Moyen Âges, Paris 1927.

Loт F., La fin du monde antique et les débuts du Moyen Âges, $2^{\mathrm{e}}$ section: L'effondrement de l'Empire et l'affaiblissement de l'idée monarchique, Paris 1938.

Markus R.A., Chrześcijaństwo w świecie rzymskim, tłum. R. Turzyński, Warszawa 1978.

Marrou H.-I., L'Église de l'Antiquité tardive 303-604, Paris 1985.

Marrou H.-I., Zmierzch Rzymu czy późna starożytność? III-VI wiek, thum. M. Węcowski, Warszawa 1997.

Mazzarino M., The end of the ancient world, London 1966.

MączyŃsKa M., Wędrówki ludów. Historia niespokojnej epoki IV i Vw., Warszawa 1996.

PAŁUBICKI W. - IluK J., Matżeństwo i rodzina $w$ dawnym judaizmie i starożytnym chrześcijaństwie, Gdańsk 1995.

Pierrard P., Historia Kościoła katolickiego, tłum. T. Szafrański, Warszawa 1984.

RAHNER H., Kościót i państwo we wczesnym chrześcijaństwie, tłum. M. Radożycka, Warszawa 1986. 
Starowieyski M., Pisarze pogańscy o chrześcijaństwie, PP 102 (1985) nr 1, 18-30; 102 (1985) nr 2, 181-194; 102 (1985) nr 3, 343-357.

STRZELCZYK J., Wandalowie i ich afrykańskie państwo, Warszawa 1992.

ŚRUTWA J., Praca w starożytnym chrześcijaństwie afrykańskim, Lublin 1983.

Verbraken P., Narodziny $i$ wzrost Kościoła od czasów apostolskich do VIII w., thum.

K. Dembińska, Katowice 1988.

Vogt J., Upadek Rzymu, tłum. A. Łukaszewicz, Warszawa 1993.

WinOwski L. Stosunek chrześcijaństwa pierwszych wieków do wojny, Lublin 1947.

Wypustek-Krzyszowski A., Chrześcijanie a armia rzymska - „De corona militis” Tertuliana, w: Pod znakami Aresa i Marsa. Materiaty z konferencji naukowej „,Wojna $i$ wojskowość w starożytności”, Kraków, 24-26 września 1993, red. E. Dąbrowa, Zeszyty Naukowe Uniwersytetu Jagiellońskiego 1166, Prace Historyczne, z. 117, Kraków 1995, 125-142.

ZAKRZEWSKI K., U schytku świata antycznego, Warszawa 1964. 